\title{
Physicochemical, microbiological and sensory characteristics of cow's milk Kashkaval cheese ripened at different temperatures
}

\author{
*Ivanova, M., Markova, A. and Ivanov, G. \\ Technological Faculty, University of Food Technologies, 26 Maritsa Blvd., 4002 Plovdiv, Bulgaria
}

\author{
Article history: \\ Received: 29 September \\ 2020 \\ Received in revised form: 29 \\ October 2020 \\ Accepted: 1 January 2021 \\ Available Online: 3 April \\ 2021
}

Keywords:

Kashkaval cheese,

Ripening,

Microbiology evaluation,

Sensory evaluation,

Pasta filata cheese,

Hard cheese

DOI:

https://doi.org/10.26656/fr.2017.5(2).552

\begin{abstract}
Kashkaval is a hard cheese produced in Eastern Europe and consumed after ripening. The influence of ripening temperature $\left(9 \pm 1^{\circ} \mathrm{C}, 11 \pm 1^{\circ} \mathrm{C}\right.$ and $\left.13 \pm 1^{\circ} \mathrm{C}\right)$ of cow's milk Kashkaval cheese on its physicochemical, microbiological and sensory characteristics was studied. For the ripening period no statistically significant differences $(\mathrm{P}>0.05)$ in the indicators dry matter, fat content, salt and protein were found. A slight decrease in active acidity was observed during the maturation process which tendency was more pronounced in the experimental samples ripened at higher temperatures $\left(13.0 \pm 1.0^{\circ} \mathrm{C}\right)$. It was found that lowering the ripening temperature of Kashkaval cheese was accompanied by a prolongation of the lag phase in the development of lactic acid microflora. A significantly higher amount of lactic acid microorganisms $(\mathrm{P}<0.05)$ in cheese samples matured at $13 \pm 1^{\circ}$ $\mathrm{C}$ was established. The chosen temperature regime of maturation did not affect the number of psychrotrophic microorganisms $(\mathrm{P}>0.05)$. The absence of unwanted side microflora in fresh cheese was established, which was an important prerequisite for the normal course of the maturing processes and the formation of a characteristic sensory profile of the cheese. Kashkaval cheese ripened at $13 \pm 1^{\circ} \mathrm{C}$ for 45 days was characterized by the highest overall sensory score comparable to Kashkaval cheese ripened at $9 \pm 1{ }^{\circ} \mathrm{C}$ and $11 \pm 1^{\circ} \mathrm{C}$ for 60 days. The obtained results demonstrated that the higher ripening regime could be successfully used to reduce production costs without changing the specific physicochemical, microbiological and sensory characteristics of Kashkaval cheese from cow milk.
\end{abstract}

\section{Introduction}

The microorganisms play an important role in the quality and safety of cheeses during their maturation and storage (Tilocca et al., 2020). Their development in dairy products is mainly influenced by temperature and the period of ripening and storage (Leclercq-Perlat et al., 2015). The process of fermentation of lactose to lactic acid in the cheese takes place mainly by the action of the lactic acid bacteria from the starter microflora. Enzymes released after autolysis of starter lactic acid bacteria are involved in the proteolysis of cheese paracasein, which is actively involved in the maturation process (Leroy and De Vuyst, 2004). An important role of starter cultures is to provide a suitable environment (redox potential, $\mathrm{pH}$ and regulated water content) necessary for the activity of residual rennet enzyme involved in the maturation process, as well as for the development of secondary microflora (Macedo et al., 2004). Non-starter microorganisms play a significant role in the microflora of mature cheeses (Settanni and Moschetti, 2010). The non-starter lactic acid bacteria in the cheese are usually mesophilic lactobacilli and/or cocci. The development of microflora in cheeses plays an important role in the formation of their specific sensory characteristics (Blaya et al., 2018). This is accomplished through several key mechanisms such as hydrolysis of proteins to peptides and free amino acids, metabolism of free amino acids and hydrolysis of triglycerides to fatty acids.

The sensory characteristics of the cheeses are formed both during the ripening process and during their refrigerated storage. The specific sensory profile of different types of cheese is determined by their physicochemical parameters, as well as the degree of lipolysis and proteolysis. By breaking down proteins into peptides and free amino acids, proteolysis contributes to the formation of the taste of the cheese (Jerónimo and Malcata, 2013). The formation of some short-chain peptides, as well as the presence of the amino acids 
isoleucine, tyrosine and arginine, gives the cheese an undesirable bitter taste. Other amino acids (lysine, proline) form a sweet-bitter, sweet (alanine, glycine, serine, and tryptophan) or sour taste (glutamine, histidine, and asparagine) of the cheese (McSweeney et al., 1997). Organic acids formed as a result of lipolysis and glycolysis processes largely determine the intensity of the taste and aroma of the cheese (Akalin et al., 2002).

According to the Bulgarian National Standard (BNS) 14:2010, Kashkaval cheese is hard cheese. It is from the group of "Pasta filata" cheeses but with lower moisture content which curd is subjected to cheddaring, cooking, stretching, moulding and ripening, mainly produced in Eastern Europe (Bylund, 2015). To the best of our knowledge, any studies about the influence of different regimes of ripening on the Kashkaval sensory and microbiology characteristics were not available. Therefore, we hypothesized those different modes of ripening, than the traditional one, can improve the quality of Kashkaval. Moreover, the ripening regime can reduce production costs and improve the nutrition and sensory properties of this product.

Therefore, the present research aimed to study the influence of the temperature regime of ripening on the development of the microflora in Kashkaval cheese from cow's milk and its influence on the formation of specific sensory characteristics.

\section{Materials and methods}

\subsection{Kashkaval cheese manufacture}

Kashkaval samples were prepared from four batches in the amount of $5000 \mathrm{~L}$ of milk. They were produced under industrial conditions in the company "Bor Chvor" Ltd. The cow's milk, meeting the normative requirements, was subjected to separation in order to clarify milk and to standardize milk (casein to fat content ratio was 0.70 ) at $35-45^{\circ} \mathrm{C}$, thermisation at $63 \pm 2^{\circ} \mathrm{C}$ for $15-20 \mathrm{~s}$ and cooled to a temperature of $33 \pm 1^{\circ} \mathrm{C}$, at which curd manufacture was performed. A starter culture containing $S$. thermophilus, L. delbrueckii ssp. bulgaricus and L. helveticus in amount of $1 \%$ was added. Calcium dichloride solution (50\%) in the amount of 30 $\mathrm{mL}$ per $100 \mathrm{~L}$ of milk, previously diluted in water in 1:10 ratio, was added. Rennet (previously diluted in water in $1: 10$ ratio) quantity was so that the beginning of coagulation process took place 9-10 mins after enzyme addition and complete coagulation was established after 45 mins. When a set coagulum was formed, it was cut into 3-4 s grains with a rest for 5-10 mins and then cut again into $6-8 \mathrm{~mm}$ grains. After cutting the coagulum, grains were heated at $38-41^{\circ} \mathrm{C}$. After whey titratable acidity increased with $3-4^{\circ} \mathrm{T}$, the draining process took place. Collecting of curd for pressing and cheddaring was done. After 1-1.5 hrs, $\mathrm{pH}$ reached 5.2-5.3, and the curd was further milled and salted in a hot water solution (at $72^{\circ} \mathrm{C}$ and $14 \%$ salt content). Then it was formed in 1 $\mathrm{kg}$ mould. Fresh Kashkaval rested for $15 \mathrm{hrs}$, and then it was dried and packed. The ripening process was performed at three different temperatures $9 \pm 1^{\circ} \mathrm{C}$ (control sample), $11 \pm 1^{\circ} \mathrm{C}$ and $13 \pm 1{ }^{\circ} \mathrm{C}$ temperature of ripening and relative humidity $70-80 \%$ for 60 days.

\subsection{Physicochemical analyses}

Determination of cheese dry matter - Bulgarian National Standard (BNS) EN ISO 5534:2005; Determination of cheese protein content - BNS EN ISO 8968-1:2014 Determination of cheese salt $(\mathrm{NaCl})$ content - BNS 8274:1982; Determination of titratable acidity BNS 1111:1980; Potentiometric determination of active acidity $(\mathrm{pH})$; Determination of cheese fat content ISO 3433:2008.

\subsection{Microbiological analyses}

Cheese samples were prepared for microbiological examination according to BNS EN ISO 6887-5:2020.

Determination of the total number of lactobacilli and streptococci - cultures of selective synthetic nutrient media of M17 and MRS were performed. The analysis was done according to BNS ISO 7889:2005 and BNS ISO 9232:2005.

Determination of the number of psychrotrophic microorganisms - according to the methodology described in BNS ISO 17410:2019. Hydrolysed milk agar medium was used.

Determination of the number of moulds and yeasts is performed by deep sowing in Yeast Extract Glucose Chloramphenicol Agar (Merck), as described in BNS ISO 6611:2006.

Determination of coliform bacteria and E. coli - the number of coliform bacteria and E. coli was determined by chromogenic agar for coliforms Chromocult (Merck) according to ISO 4832:2006.

\subsection{Sensory analysis}

The sensory evaluation of the fresh cheeses was conducted in accordance with the Bulgarian National Standard BNS $15612: 1983$ by 20 panellists. The evaluation criteria were the following: taste and aroma 20 points, consistency - 15 points, structure and cut surface - 10 points, appearance and colour -5 points (maximum overall score - 50 points). 


\subsection{Statistical analyses}

Computer processing of results was performed using Microsoft Excel 2010 (ANOVA). Multiple comparisons were made with the LSD procedure. Results are presented as the mean $\pm \mathrm{SD}$ (standard deviation) $(\mathrm{n}=4)$.

\section{Results and discussion}

\subsection{Physicochemical analysis}

The change in the content of the main components of Kashkaval cheese during the ripening period is presented in Table 1. The obtained data showed that the experimental Kashkaval cheese samples had standard physicochemical parameters.

In the present study, no statistically significant $(\mathrm{P}>0.05)$ changes in the values of dry matter, total protein, fat and salt content during the ripening period (from the $1^{\text {st }}$ to the $60^{\text {th }}$ day) were found. A slight decrease $(\mathrm{P}<0.05)$ in the active acidity during the ripening process was found. This tendency was most pronounced in the experimental samples ripened at higher temperatures $\left(13.0 \pm 1.0^{\circ} \mathrm{C}\right)$. Our results were comparable with those of Sorrentino et al. (2013) who established a significant difference $(\mathrm{P}<0.05)$ of ripening temperature on $\mathrm{pH}$ of the ripened Scamorza (pasta filata) cheese.

\subsection{Microbiological analysis}

The development of lactic acid bacteria during the maturation process in the studied samples of cow's milk cheese is presented in Figure 1.

In samples matured at lower temperatures $\left(9 \pm 1^{\circ} \mathrm{C}\right.$ and $11 \pm 1^{\circ} \mathrm{C}$ ), the number of lactic acid microorganisms on day 15 remained below $10^{5} \mathrm{CFU} / \mathrm{g}$. This indicated that the decrease in the ripening temperature of Kashkaval cheese was accompanied by a prolongation of the lag phase in the development of the lactic acid microflora. After the $15^{\text {th }}$ day of the maturation process at $13.0 \pm 1.0^{\circ} \mathrm{C}$, the lactic acid bacteria entered the exponential phase of their development and on the $60^{\text {th }}$ day, their number reached $1.4 \pm 0.03 \cdot 10^{7} \mathrm{CFU} / \mathrm{g}$. Lactic acid microflora of Kashkaval cheese entered the exponential phase of development after the $30^{\text {th }}$ day of ripening at $9.0 \pm 1.0^{\circ} \mathrm{C}$ and $11.0 \pm 1.0^{\circ} \mathrm{C}$. At the end of the maturation process of these samples, the total number of lactic acid bacteria remained below $10^{6} \mathrm{CFU} / \mathrm{g}$, which was significantly lower $(\mathrm{P}<0.05)$ compared to the values of the cheese samples matured at $13.0 \pm 1.0^{\circ} \mathrm{C}$. These data showed that even minimal temperature differences $\left(2^{\circ} \mathrm{C}\right)$ in the ripening regimes could have a significant impact on the development of the lactic acid microflora in Kashkaval cheese. Similar results were obtained by other researchers who found a significant influence of ripening temperature on lactic acid bacteria growth (McSweeney, 2007).

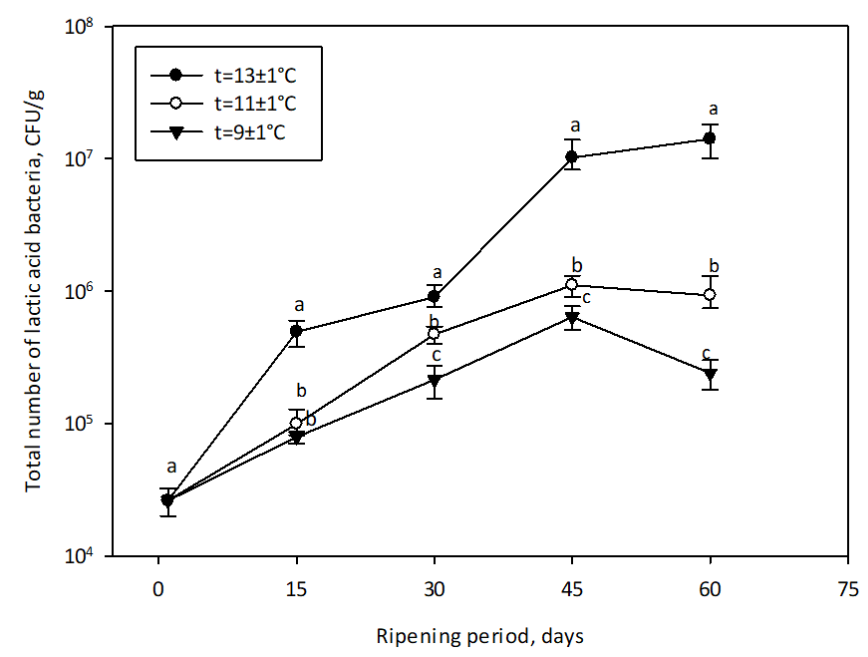

Figure 1. Changes in the total number of lactic acid bacteria in Kashkaval cheese during ripening at different temperatures. Different letters between days show statistically significant differences $(\mathrm{P}<0.05)$ during ripening.

An increase in the number of psychrotrophic microorganisms was observed from $2.2 \pm 0.04 .10^{4} \mathrm{CFU} / \mathrm{g}$ to $3.4 \pm 0.05 .10^{6} \mathrm{CFU} / \mathrm{g}$ during the 60 -day maturation period (Figure 2). Slightly more intensive growth of the psychrotrophic microflora during the first 15 days of maturation was observed in the samples matured at $13.0 \pm 1.0^{\circ} \mathrm{C}$

However, at the end of the maturation process, no

Table 1. Physicochemical composition of Kashkaval cheese during ripening at different temperatures

\begin{tabular}{lcccccc}
\hline & \multicolumn{5}{c}{ Temperature of ripening } \\
\cline { 2 - 7 } & \multicolumn{2}{c}{$9 \pm 1^{\circ} \mathrm{C}$} & \multicolumn{2}{c}{$11 \pm 1^{\circ} \mathrm{C}$} & $13 \pm 1^{\circ} \mathrm{C}$ \\
\cline { 2 - 7 } & $1^{\text {st }}$ day & $60^{\text {th }}$ day & $1^{\text {st }}$ day & $60^{\text {th }}$ day & $1^{\text {st }}$ day & $60^{\text {th }}$ day \\
\hline Dry matter, \% & $58.1 \pm 0.4^{\mathrm{b}}$ & $58.2 \pm 0.7^{\mathrm{b}}$ & $58.3 \pm 0.7^{\mathrm{b}}$ & $58.5 \pm 0.6^{\mathrm{b}}$ & $57.9 \pm 0.5^{\mathrm{b}}$ & $58.4 \pm 0.6^{\mathrm{b}}$ \\
Total protein, \% & $22.1 \pm 0.7^{\mathrm{c}}$ & $21.9 \pm 0.6^{\mathrm{c}}$ & $22.0 \pm 0.4^{\mathrm{c}}$ & $21.8 \pm 0.6^{\mathrm{c}}$ & $22.4 \pm 0.5^{\mathrm{c}}$ & $21.9 \pm 0.6^{\mathrm{c}}$ \\
Fat, \% & $34.9 \pm 0.7^{\mathrm{d}}$ & $35.0 \pm 0.8^{\mathrm{d}}$ & $35.0 \pm 0.9^{\mathrm{d}}$ & $35.4 \pm 0.5^{\mathrm{d}}$ & $35.2 \pm 0.6^{\mathrm{d}}$ & $35.3 \pm 0.7^{\mathrm{d}}$ \\
$\mathrm{NaCl} \%$ & $1.8 \pm 0.9^{\mathrm{e}}$ & $2.0 \pm 0.6^{\mathrm{e}}$ & $1.9 \pm 0.5^{\mathrm{e}}$ & $2.1 \pm 0.8^{\mathrm{e}}$ & $1.8 \pm 0.7^{\mathrm{e}}$ & $1.9 \pm 0.5^{\mathrm{e}}$ \\
$\mathrm{pH}$ & $5.61 \pm 0.05^{\mathrm{a}}$ & $5.50 \pm 0.04^{\mathrm{b}}$ & $5.61 \pm 0.05^{\mathrm{a}}$ & $5.46 \pm 0.06^{\mathrm{b}}$ & $5.61 \pm 0.05^{\mathrm{a}}$ & $5.28 \pm 0.07^{\mathrm{c}}$ \\
\hline
\end{tabular}

${ }^{\text {a-e }}$ Different letters in the same row show statistically significant differences $(\mathrm{P}<0.05)$ after 60 days of ripening at different temperatures. 
statistically significant $(\mathrm{P}>0.05)$ differences in the number of psychrotrophic microorganisms were found between the samples matured in the three experimental regimes. The results obtained in the present study showed that the variations in the ripening temperature of cow's milk cheese in the range from $8^{\circ} \mathrm{C}$ to $14^{\circ} \mathrm{C}$ did not have a significant effect $(\mathrm{P}>0.05)$ on the growth of the psychrotrophic microflora.

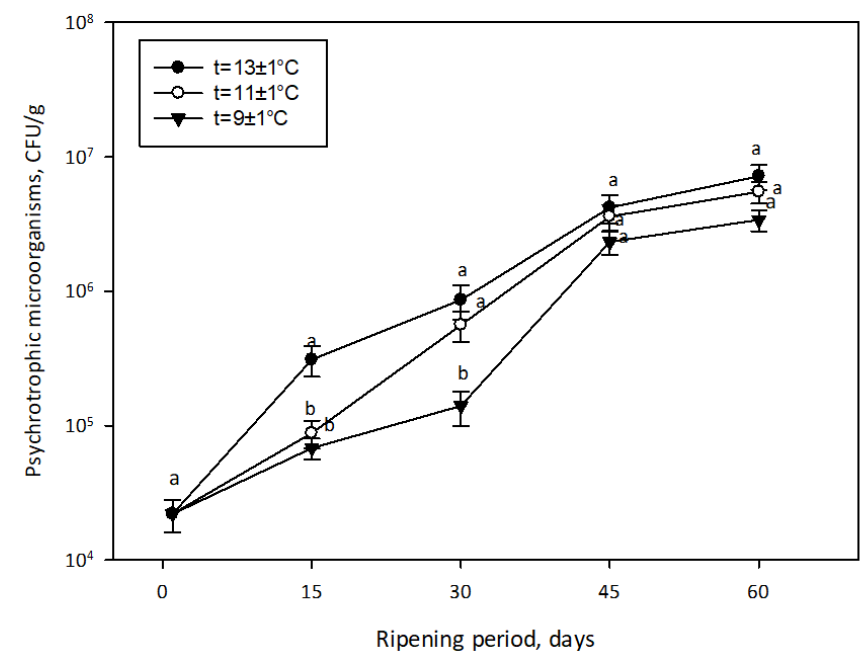

Figure 2. Changes in the psychrotrophic microorganisms in Kashkaval cheese during ripening at different temperatures. Different letters between days show statistically significant differences $(\mathrm{P}<0.05)$ during ripening.

The present study did not detect the development of moulds, yeasts, coliforms and E. coli during the maturation of Kashkaval cheese samples (Table 2). The low levels of non-starter microflora demonstrated good production and hygienic practices in the process of production of the experimental samples, results confirmed by Tripaldi et al. (2018).

Table 2. Mould, yeasts, coliforms and E. coli in Kashkaval cheese during ripening at different temperatures

\begin{tabular}{cccccc}
\hline \multirow{2}{*}{$\begin{array}{c}\text { Temperature } \\
\text { of ripening } \\
\left({ }^{\circ} \mathrm{C}\right)\end{array}$} & \multicolumn{5}{c}{$\begin{array}{c}\text { Moulds and yeasts, coliforms and E. coli } \\
\text { (CFU/g) }\end{array}$} \\
\cline { 2 - 6 } & 1 & 15 & 30 & 45 & 60 \\
\hline $13.0 \pm 1.0$ & $<10$ & $<10$ & $<10$ & $<10$ & $<10$ \\
$11.0 \pm 1.0$ & $<10$ & $<10$ & $<10$ & $<10$ & $<10$ \\
$9.0 \pm 1.0$ & $<10$ & $<10$ & $<10$ & $<10$ & $<10$ \\
\hline
\end{tabular}

The absence of unwanted side microflora in fresh cheese was an important prerequisite for the normal ripening process and the formation of the characteristic sensory characteristics.

\subsection{Sensory evaluation}

In the present study, sensory analysis of Kashkaval cheese samples was performed after a 45-day and 60-day ripening period (Figure 3).
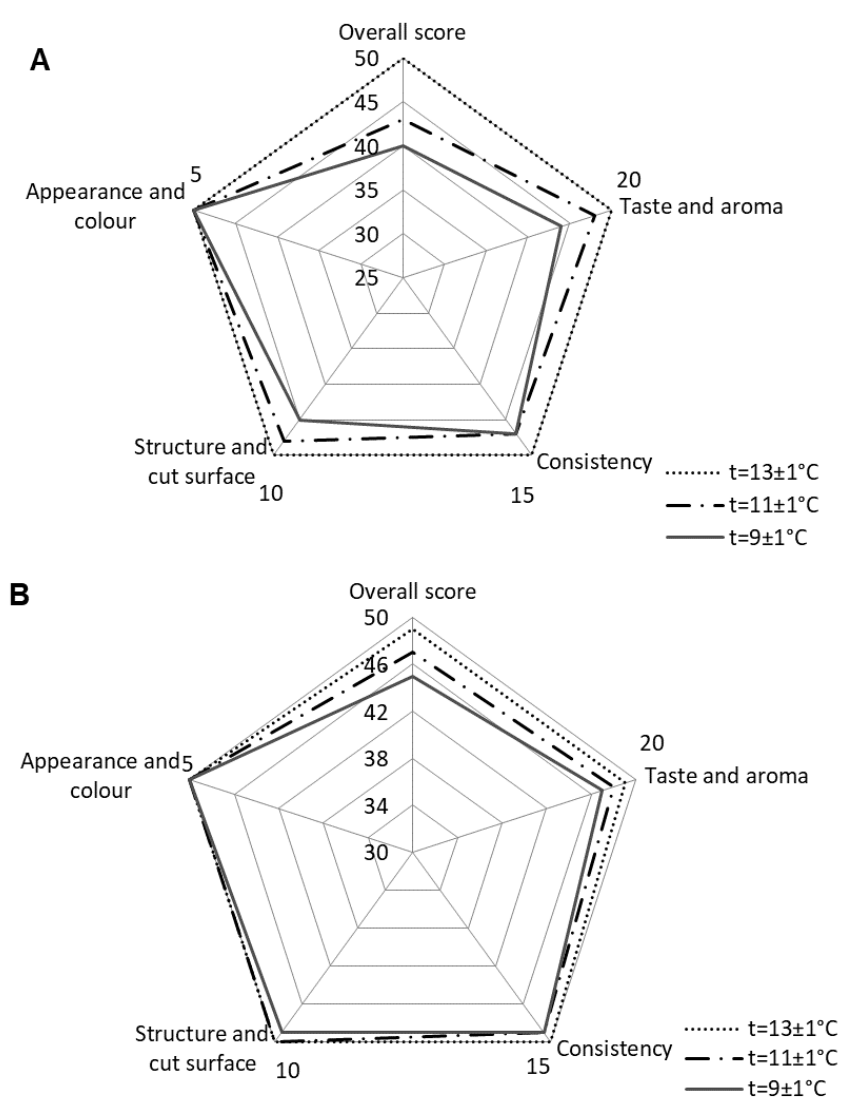

Figure 3. Sensory profile of Kashkaval cheese ripened at different temperatures for 45 days (A) and 60 days (B).

The obtained results showed that the ripening temperature did not have a significant effect $(\mathrm{P}>0.05)$ on the indicator appearance and colour of Kashkaval cheese. The lowest value $(\mathrm{P}<0.05)$ for the indicators taste and aroma, structure and cut surface were obtained for the samples matured at $9.0 \pm 1.0^{\circ} \mathrm{C}$, and the highest, for the samples, mature at $13.0 \pm 1.0^{\circ} \mathrm{C}$. Probably, the delayed microbial development (Figure 1) in the Kashkaval cheese ripened at $9.0 \pm 1.0^{\circ} \mathrm{C}$ was the reason for the slower biochemical transformations responsible for the formation of its taste and aroma. At higher ripening temperatures, these processes were more intense. This trend was also confirmed by the high overall sensory evaluations of Kashkaval cheese samples on day 60, matured at $13.0 \pm 1.0^{\circ} \mathrm{C}$. Samples of Kashkaval cheese, matured at lower temperatures, received lower scores for the indicators cut surface and consistency. The main disadvantages observed in these samples were inhomogeneous consistency and the presence of fibres. The presence of such defects was an indication of an incomplete maturation process. Di Cagno et al. (2012) observed the same tendency during the ripening of Caciocavallo cheese.

\section{Conclusion}

The decrease in the ripening temperature of the Kashkaval cheese in the range from $14^{\circ} \mathrm{C}$ to $8^{\circ} \mathrm{C}$ was accompanied by a prolongation of the lag phase in the 
development of the lactic acid microflora. At the same time, variations in the ripening temperature in the same range did not significantly affect the growth of psychrotrophic microorganisms in cheese. The formation of the characteristic sensory profile of cheese from cow's milk was significantly influenced by the applied temperature regime of ripening. Kashkaval cheese samples ripened at $13.0 \pm 1.0^{\circ} \mathrm{C}$ received the highest overall organoleptic evaluation. The obtained results demonstrated that the higher ripening regime of Kashkaval cheese from cow milk indeed was economically feasible for manufactures without changing its specific physicochemical, microbiological and sensory characteristics.

\section{Conflict of interest}

The authors declare no conflict of interest.

\section{References}

Akalin, A.S., Gönç, S. and Akbaş, Y. (2002). Variation in organic acid content during ripening of pickle white cheese. Journal of Dairy Science, 85(7), 16701676. https://doi.org/10.3168/jds.S0022-0302(02) 74239-2

Blaya, J., Barzideh, Z. and LaPointe, G. (2018). Symposium review: Interaction of starter cultures and nonstarter lactic acid bacteria in the cheese environment. Journal of Dairy Science, 101(4), 3611 -3629. https://doi.org/10.3168/jds.2017-13345.

Bulgarian National Standard (BNS) (1980). Milk and dairy products. Determination of acidity. (BNS 1111:1980). Bulgaria.

Bulgarian National Standard (BNS) (2010). Bulgarian Kashkaval. (BNS 14: 2010). Bulgaria.

Bulgarian National Standard (BNS) (1983). Dairy products. Sensory analysis. (BNS 15612: 1983). Bulgaria.

Bulgarian National Standard (BNS) (1982). Determination of cheese salt $(\mathrm{NaCl})$ content. (BNC 8274: 1982). Bulgaria.

Bulgarian National Standard (BNS) (2005). Cheese and processed cheese - Determination of the total solids content (BNS EN ISO 5534: 2005). Bulgaria.

Bulgarian National Standard (BNS) EN ISO 6887-5. (2020). Microbiology of the food chain - Preparation of test samples, initial suspension and decimal dilutions for microbiological examination - Part 5: Specific rules for the preparation of milk and milk products. (BNS EN ISO 6887-5:2020). Bulgaria.

Bulgarian National Standard (BNS) EN ISO 8968-1. (2014). Milk and milk products - Determination of nitrogen content - Part 1: Kjeldahl principle and crude protein calculation. (BNS EN ISO 8968-1: 2014). Bulgaria.

Bulgarian National Standard (BNS) ISO 17410. (2019). Microbiology of the food chain - Horizontal method for the enumeration of psychrotrophic microorganisms. (BNS EN ISO 17410: 2019). Bulgaria.

Bulgarian National Standard (BNS) ISO 6611. (2006). Milk and milk products - Enumeration of colonyforming units of yeasts and/or moulds - Colonycount technique at 25 degrees C. (BNS EN ISO 6611:2006). Bulgaria.

Bulgarian National Standard (BNS) ISO 7889. (2005). Yogurt - Enumeration of characteristic microorganisms - Colony-count technique at 37 degrees C. (BNS EN ISO 7889:2005). Bulgaria.

Bulgarian National Standard (BNS) ISO 9232. (2005). Yogurt - Identification of characteristic microorganisms (Lactobacillus delbrueckii ssp. bulgaricus and Streptococcus thermophilus). (BNS EN ISO 9232:2005). Bulgaria.

Bylund, G. (2015). Cheese. In Gösta Bylund, Tetra Pak Processing Systems AB (Ed.), Dairy processing handbook $\left(3^{\text {rd }}\right.$ ed.). Lund: Tetra Pak Processing Systems AB.

Di Cagno, R., De Pasquale, I., De Angelis, M. and Gobbetti, M. (2012). Accelerated ripening of Caciocavallo Pugliese cheese with attenuated adjuncts of selected nonstarter lactobacilli. Journal of Dairy Science, 95(9), 4784-4795. https:// doi.org/10.3168/jds.2011-5283

ISO (International Organization for Standardization). (2008). Cheese - Determination of fat content Van Gulik method (ISO 3433: 2008).

ISO (International Organization for Standardization). (2006). Microbiology of food and animal feeding stuffs - Horizontal method for the enumeration of coliforms - Colony-count technique. (ISO 4832: 2006).

Jerónimo, E. and Malcata F.X. (2013). Sensory characteristics of cheese. In Preedy, V.R., Watson, R.R. and Patel, V.B. (Eds). Handbook of cheese in health. Human Health Handbooks, 6, p. 39-52. Wageningen Academic Publishers. https:// doi.org/10.3920/978-90-8686-766-0_3

Leclercq-Perlat, M.N., Sicard, M., Perrot, N., Trelea, I.C., Picque, D. and Corrieu, G. (2015). Temperature and relative humidity influence the ripening descriptors of Camembert-type cheeses throughout ripening. Journal of Dairy Science, 98(2), 13251335. https://doi.org/10.3168/jds.2014-8916 
Leroy, F. and De Vuyst, L. (2004). Lactic Acid Bacteria as Functional Starter Cultures for the Food Fermentation Industry. Food Science and Technology, 15(2), 67-78. https://doi.org/10.1016/ j.tifs.2003.09.004

Macedo, A.C., Tavares, T.G. and Malcataa, F.X. (2004). Influence of native lactic acid bacteria on the microbiological, biochemical and sensory profiles of Serra da Estrela cheese. Food Microbiology, 21(2), 233-240. https://doi.org/10.1016/S0740-0020(03) 00064-9

McSweeney, P.L.H. (2007). The microbiology of cheese ripening. In McSweeney, P.L.H. (Ed.), Cheese problems solved, p. 117-132. USA: Woodhead Publishing Series in Food Science, Technology and Nutrition. https:// doi.org/10.1533/9781845693534.117

McSweeney, P.L.H., Nursten, H.E. and Urbach, G. (1997). Flavours and off-flavours in milk and dairy products. In Fox, P.F. (Ed.), Advanced Dairy Chemistry Lactose, Water, Salts and Vitamins. Vol. 3, $2^{\text {nd }}$ ed., p. 403-468. London: Chapman and Hall. https://doi.org/10.1007/978-1-4757-4409-5_10

Settanni, L. and Moschetti, G. (2010). Non-starter lactic acid bacteria used to improve cheese quality and provide health benefits. Food Microbiology, 27(6), 691-697. https://doi.org/ 10.1016/j.fm.2010.05.023

Sorrentino, E., Tipaldi, L., Pannella, G., La Fianza, G., Succi, M. and Tremnte, P. (2013). Influence of ripening conditions on Scamorza cheese quality. International Journal of Agricultural and Biological Engineering, 6(3), 71-7. https://doi.org/10.3965/ j.ijabe.20130603.009

Tilocca, B., Costanzo, N., Morittu, V.M., Spina, A.A., Soggiu, A., Britti, D., Roncada, P. and Piras, C. (2020). Milk microbiota: Characterization methods and role in cheese production. Journal of Proteomics, 210, 103534. https://doi.org/10.1016/ j.jprot.2019.103534

Tripaldi, C., Palocci, G., Di Giovanni, S., Marri, N., Boselli, C., Giangolini, G. and Amatiste S. (2018). Microbiological and chemical characteristics of pasta filata type cheese from raw ewe milk, using thermophilic and mesophilic starters. Journal of Food Safety and Food Quality, 69(4), 105-130. https://doi.org/10.2376/0003-925X-69-123 